\title{
Communication of Intercultural Couples Through Identity Negotiation During Courtship
}

\author{
Gerry Wahyu Dewatara ${ }^{1, *}$ Sari Monik Agustin ${ }^{2}$
}

\author{
${ }^{1}$ Universitas Indonesia \\ ${ }^{2}$ Universitas Indonesia \\ * Corresponding Author: dewataragerry@gmail.com
}

\begin{abstract}
This study aims to discover and to analyze how interfaith couples negotiate their identities with each other. In Indonesia, especially in Jakarta, individuals often meet and interact with people from different backgrounds and as a result, some fall in love. However, partners who belong to distinct cultures will encounter numerous obstacles and will specifically face resistance from their social environment. This study uses a qualitative research methodology with the constructivist paradigm. The results of this study revealed that religious identity is not an obstacle for respondents to proceed to the stage of marriage. However, identity negotiation is required for couples to obtain the blessings of their social environments, which in this case concern the family of one party.
\end{abstract}

Keywords: Communication, Negotiation, Identity, Identity Negotiation, Intercultural Relationship

\section{INTRODUCTION}

Increasing intercultural interactions have resulted in individuals from discrete communities falling in love. Yahya (2014) said that falling in love with someone from a different cultural or religious background becomes very possible as the world becomes more multicultural. Interfaith relations involve intimate interpersonal contact (dating, courtship, and marriage) between people from different religious beliefs (Judaism, Christianity, Islam, etc.). On the other hand, intercultural relations are those that occur between people who come from different societies. Residents of Indonesia strongly adhere to the religious and cultural values of the nation. Religion is a very important aspect of the Indonesian way of life and it is an inevitable part of family, politics, economy, education and all other social institutions (Sewenet et.al, 2017).

Before deciding to marry, couples undergo a period of courtship. During this time, couples have to get to know each other and build their relationships before moving to the more serious stage of thinking of a future together (Niehuis et al, 2006).

Problems that are generally found in couples professing the same religious beliefs are also found in couples with differing faiths. However, the common issues become more problematic for interfaith couples because of their fundamental religious differences, and this circumstance provides an additional "challenge" for them to overcome (Martin and Nakayama, 2010).

Yahya et al (2016) asserted that the ideas of intercultural relations and differences in belief are contrary to the conventional principle of endogamy, or the custom of marrying within one's community. This policy has long been studied in many cultures and still prevails in Indonesia. Although interfaith and intercultural relations (heterogamy) may be witnessed, such couples often face discrimination in the form of exclusion and rejection by their families. As a result, heterogamous couples are often found to end relationships more easily than homogamous (same belief) couples (Gaines and Brennan 2001).

Findings from studies on communication and conflict resolution are often used to teach couples how to improve the quality of their relationships (Floyd and Markman, 1984; Markman, Silvern, Clements, \& Kraft-Hanak, 1993). Superior communication skills can predict satisfaction and relationship stability in any situation (Markman, Renick, Floyd, Stanley, \& Clements, 1993).

Intercultural communication skills indicate the ability of mindfulness, which is defined by Ting-Tommey (1999) as readiness to shift one's frame of reference or the motivation to use new categories to understand cultural or ethnic differences. It also involves a person's preparedness to experiment with creative opportunities 
through decision-making and problem solving. Research conducted by Reiter and Gee (2008) claims that effective communication and reliable support is most needed from partners to achieve satisfaction in relationships that are inter-religious or intercultural.

In a study conducted by Adegbola and his colleagues (2018) on international students, identity negotiations were found to be very helpful in dealing with and resolving conflicts that occur among domestic students. Swann (1987) stated that the process of negotiating one's identity in the face of social realities is not based on the communication activities conducted solely by the recipient of a message; in fact, it is jointly negotiated by both the speaker and receiver.

Therefore, it is necessary for two people in intercultural or interfaith relationships to perform identity negotiations. Ting-Toomey (1999: 39) asserts that the notion of, identity negotiation emphasizes the fact that identities self-conceptions are to be regarded as explanatory mechanisms for the process of intercultural communication. Identity involves various aspects of an individual: the culture, ethnicity, religion, social class, gender, sexual orientation, professionalism, and family roles as well as the person's reflective self-image which is constructed, experienced, and communicated by the individual in specific interaction situations. Thus, the research question posed by this study is: how do intercultural couples navigate through identity negotiations during their courtship?

\section{LITERATURE REVIEW}

\subsection{Identity Negotiation}

Negotiation refers to bargaining to reach an agreement. Robbins (2003) defines negotiation as a process in which two parties or more exchange goods and services and try to agree on the same thing. According to Jackman (2005), negotiation is a process that occurs between two or more parties who at first have different thoughts but eventually come to an agreement.

According to Vignoles (2017), identity is the answer to the question, "who are you?" This question is shaped explicitly or implicitly, at the level of the personal or the collective, in reference to others or oneself. According to Jenkins (1996), identity refers to how a person or society distinguishes selfhood from other individuals and other societies. On the other hand, Katzenstein (1996: 59) describes identity as the picture of the self and others who are mutually constructing and developing. Deng (1995) defines identity as a way of elucidating how a person or group interprets the sense of self and how people or groups are interpreted by others through the lens of race, ethnicity, religion, language and culture.
According to Swann (1987) the process of identity negotiation presents several strategies employed by individuals to prove themselves:

- Some are interpersonal, involving a person's ability to bring others to perceive them the way they see themselves.

- Another strategy could be intrapsychic, in which a person sees more evidence of confirmation than actually exists.

Swann (1987) claims that one of these strategies is automatic and does not require effort while the other is consciously conceived and performed and requires determination.

\subsection{Communication and Intercultural Relationships}

Culture is defined as a series of situational models of attitudes and thoughts (Hall, 1989). Philipsen (in Griffin, 2003) describes culture as a social construction and as a pattern of symbols, meanings, opinions, and rules inherited historically.

Communication, according to Gamble and Gamble (2013) is the deliberate or accidental process of conveying meaning. It is a skill that is required to transmit messages to others and communication is considered successful if the behavior or attitude of one person influences the conduct and approach of another in the desired manner (Gamble \& Gamble, 2013). Littlejohn and Foss (2008) state that the theory of communication is a view and strategy that shapes the tools and framework for something to be accomplished. In theoretical terms, the communication process constructs the forms and the communication rules that are required to be created.

Intercultural communication is basically identical to other forms of communication, except for the fact that it occurs between people with different cultural backgrounds. Communication experts have defined this term in numerous ways. Martin and Nakayama (2010: 77) articulate that intercultural communication is cultural and individual, personal and contextual, and is characterized by differences and similarities. It is static and dynamic, is oriented to the present and the past, and is characterized by privileges and disadvantages. Further, intercultural communication occurs when a message that must be understood is produced by members of a particular culture for consumption of members from other cultures (Samovar \& Porter, 1994: 19).

Discourse on culture cannot be separated from the discussion of religion. According to Koentjaraningrat (1987: 180), culture is the whole system, ideas, actions and results of human work in the framework of people's lives. It is owned by humans through learning. Yojachem Wach maintains that mythological collective relations depend on God and that religion exerts a great influence 
on immaterial human culture. Social and religious interactions are patterned by how people think of God, and how they live and imagine God (Wach, 1998: 187). According to Clark and Hoover (1997), culture and religion cannot be separated and religion is vital to the theory of culture and society. For Geertz (1973), religion is a system that is useful for the building of strong, pervasive, and long-lasting moods and motivations in humans. These prevailing attitudes and stimuli result from the formulation of conceptions of the order of general existence and an enveloping notion that imbibes an aura of reality in which the created mood and motivation look uniquely realistic. Beckford and Demerath (2007) claim that while religion influences culture, religion is also influenced by culture because it is an important aspect of culture. Religious culture tends to grow and develop in line with historical events in the objective conditions of the life of the religion's adherents (Andito, ed, 1998: 282). However, religions function primarily as means of regulating and expressing what a person or society believes in cultural terms, namely in the form of ethics, art, community structures, customs, and other aspects that connote daily living McGuire (2002: 8) It is not forbidden to define religion in ways that are different from descriptions described by others.

Pogrebin (1987) emphasizes that intercultural affiliations require more "care and giving" compared to relationships between individuals who share the same culture. All activities that are performed require explanation: to themselves, to the other individual, and to the respective communities of the individuals concerned. According to Cai and Rodriguez (1996), a meeting between cultures is an arrangement of two individuals who have different communicative behaviors based on social norms that emanate from different groups, each of which holds unique values and beliefs (culture).

\subsection{Courtship in Intercultural Relationships}

According to Berscheid and Ammazzalorso (2004), a relationship occurs when two people become interdependent to the extent that changes in the behavior of one person cause changes in the other. Intimate relationships evince patterns of interaction that occur over a prolonged period of time, where partners frequently exert a strong influence on one another and affect each other's mannerisms and habits (Kelley et al., 1983). Such relationships also involve mutual dependence, strong feelings, and an overlapping of selfconcepts, but a unique romantic relationship is characterized by passion and exclusive commitment (Fiske, 2004)

Courtship is vital to relationships. According to Acre (2001), courtship is the real road to marriage. Its customs and rituals aim to provide the practice that facilitates individuals to negotiate the complex transition to marriage. How does someone look for a marriage partner? What does a person seek in a partner? What steps are taken by young adults to move from sexual attraction to love, and eventually to marriage? Courtship offers couples a chance to be educated about each other and to prepare for married life. For better or worse, it yields moral, emotional, and relationship-related education for a couple's future married life together. A good courtship tradition must foster attitudes, values, and practices that facilitate the formation of marriages that last. Benokraitis (1996) says that courtship is the process by which someone meets someone else in a social context whose purpose is to explore the possibility of whether or not the person is suitable as a life partner. Kyns (1989) states that dating is a relationship between two people of the opposite sex who feel they have an emotional attachment

Buss and Schmitt (1993) said that before entering marriage, there is a courtship process conducted by a couple. The process of dating and the relationship dynamics are often confusing, frustrating and even debilitating. Conflicts of interest between men and women's sexual strategies, often called "the war of the sexes," can be a significant source of conflict and can lead to the inability of people to discover and maintain long-term relationships. Miklousic and Oesch (2012) say this conflict is inevitable. Knowing how to change sexual strategies significantly increases the ability of people to enter into romantic interactions with others through the choice of appropriate actions and the ignoring of others to reduce interpersonal conflict between couples. Niehuis, Huston and Rosenband (2006) suggest that the courtship process can be classified into (a) defining the progression of commitments, i.e., how long to undergo courtship, whether to cohabitate or experience pregnancy outside of marriage, or whether to breaks up (b) partners interpreting each other's qualities i.e., their conflict and communication habits, how they behave verbally or nonverbally, and their sexual conduct (c) cognitive selfreflection, evaluation made by the partners about the relationship, assessments of their degree of commitment, examinations of feelings, and decision-making about marriage

A further study by Miklousic and Oesch (2012) outlines three different phases in human relations:

\section{Power of Attraction}

The first phase of a courtship is attraction. As defined by social psychology, attractiveness can be described as a positive evaluation of others and a desire to initiate contact or to build physical intimacy with them (Finkel and Baumeister, 2010).

\section{Comfort and Trust}

The second important aspect of courtship is the building of comfort and trust. Extant literature on the subject advocates the importance of taking the time to build the foundations of relationships on the basis of 
the feelings of wellbeing and conviction before moving to the next phase. (Markovik, 2007; Strauss, 2009).

\section{Seduction}

The last phase of dating is seduction, which begins only when interest, comfort, and trust are already established between two people. In general, women usually need more time to build a phase of intimacy, compared to men (Baumeister and Bratslavsky, 1999). Researchers have suggested a rule known as the seven-hour rule. It is thought that a woman usually needs a minimum accumulation of 7 hours to build a strong emotional and intellectual relationship, (based on shared interests, shared values, and deep inter-subjective understanding) before acceding to sexual activity (Markovik, 2007; Strauss, 2009). To achieve this goal, the community encourages a process of mutual self-disclosure, where one party can come to know the other at a very deep and intimate level (Markovik, 2007; Strauss, 2009).

\subsection{Social Environment}

The social environment represents a factor that can influence the change of behavior of a person or group. It includes the family atmosphere, peer setting, and community surroundings. A family is a social environment that influences individuals from birth.

Bernett and Casper (2001) define the social environment as the immediate physical and social setting in which people live or in which something happens or develops. It comprises their culture that as well as the people and institutions with whom they interact. According to Stroz (1987: 76), the social environment consists of "all conditions in the world which in certain ways influence a person's behavior, including growth and development or life process, which can also be seen as providing the environment for other generation."

\section{RESEARCH METHODOLOGY}

This study uses a qualitative approach with a constructive paradigm. The main purpose of this exemplar is to develop an understanding of social life and to discover how society understands the world in natural settings (Neuman, 2010: 103-104). According to Creswell (2010: 4), qualitative research involves methods for exploring and understanding meaning through a number of individuals or groups of people who are ascribed to social or humanitarian problems.

The research strategy used for this paper is a case study. According to Creswell (2014), case studies are investigations that are limited by time and activity and are used to carefully investigate a program, event, activity, process, a group of individuals. Using this strategy, the researcher collects information over a predetermined time period through a variety of procedures (Yin, 2002). The aim of a case study is to obtain an in-depth understanding of a narrow slice of a theme. Simply put, case studies ask how and why an event occurred or what happened in a particular situation.

Two intercultural couples who were in the courtship stage of their relationship formed the subjects of this study. The inclusion criteria of this study stipulated individuals between the ages of 18-40 years (Hurlock, 1996) who were in a relationship with a partner from a different religion. The data were collected through both structured and semi-structured recorded observations (Creswell, 2010). Each participant was also subjected to a detailed interview and asked to answer questions that were unstructured and open and were designed to elicit the views and opinions of the participants (Creswell, 2010).

The observations and interviews were further investigated using thematic analysis, a process of coding information that can produce a list of themes, model premises, complex indicators, or qualifications related to subjects, and also the phenomena that lie in-between or emerge as a combination of the four categorizations. Themes are able to describe phenomena and can better macro-enable the interpretation of phenomena. Thematic analyses are used to find patterns that are not clearly seen by other parties. After patterns are found, they are classified through the actions of labeling, defining, or describing (Poerwandari, 2007).

\section{RESEARCH RESULT}

Based on observations and in-depth interviews with the participants, researchers found that the participating partners had known each other before they decided to get into a relationship. The first pair, IS and MA, had known each other for 16 years. IS is Muslim and MA is Protestant. The second pair, GA and MN, had known each other since they were in college. GA is Muslim and $\mathrm{MN}$ is Catholic.

The results of the study revealed that when a person decides to begin a relationship with someone who belongs to a different faith, one of the parties is initially unsure before coming to accept the relationship. For some people, their belief or religion is inherently venerable and certain religious teachings do not allow relationships (marriage) with people outside their own faith.

Before the courtship stage, the participants of this study did not consider their religious differences to be important. However, when the relationship became more serious (courtship) and was characterized by attraction, comfort, trust, and seduction, the religious differences became their main concern with regard to the manner in which they could obtain the approval of their social environments. The study participants were all 
accustomed to interacting with people from different religions. IS and MA are both themselves products of interfaith marriages.

For couples of different religions, the social environment is a crucial aspect of their relationship because they may face rejection due to the differences in their beliefs This finding is supported by a study conducted by Moore (2000), which revealed that families exert a major influence on both romantic relationships and friendships. This study confirms that families instill negative attitudes toward intercultural romantic relationships and interracial friendships and that such discrimination is taught at a very young age. Research has shown that acceptance from family and relatives can estimate the satisfaction a partner derives from the relationship and that the couple will thank or blame members of their social group for the changes in their commitment levels (Hill and Peplau, 1998; Surra et al, 1988; Whyte, 1990).

Interfaith couples must excel at communicating to obtain the blessings of their families, friends, and of their communities. Only through communication can they negotiate their identities and receive acceptance from each other's social environment. The present investigation found that economic independence is vital for couples to attain the blessings of one's partner's family. An individual's economic identity is important in such cases because some of the participants hail from wealthy families. GA, for example, stated that "if I want to fight the will of my family I need to become more independent, especially in financial terms because I know once I fight the will of my family and get together with MN, I know I cannot depend on my family again." MA echoed this sentiment: "I know that IS comes from a wealthy family and that her mother married her father because of financial reasons even though they believe in different faiths, that's why I need to prove myself to her family that I can be a successful man and that he should let me marry IS.".

Apart from financial independence, the respondents asserted that good communication between partners is the paramount factor for the maintenance of harmonious relationships. The present study found that conflict is viewed by the couples as something that can strengthen the affective affiliations between the partners because they can get to know each other better through conflict. Hence, disagreement was reported to be a positive factor in the present investigation.

\section{CONCLUSION}

The present study concludes that when a person decides to enter into an interfaith relationship with someone, the relationship approach is not very different from the manner in which endogamous relationships are constructed. The investigation indicates that one of the parties in an inter-religious relationship is initially hesitant to enter into the partnership because of religious prohibitions on romantic relationships and especially marrying outside the community. When the relationship enters the courtship stage, acceptance from the social environment, especially the two families, represents the next barrier for the couple to overcome if they are to proceed to the subsequent stage. Thus, the identity negotiations of the partners in courtship are aimed more at the social environment so that they can obtain the societal mandate to continue to the next stage of their relationship.

Economic independence is a major part of the identity negotiation reported by the respondents. It was deemed crucial for the couples to attain the acceptance of their social environments and to counteract their opposition to the will of their families. The partners assumed that their financial liberation would help them overcome familial opposition and withstand the withdrawal of economic assistance, especially from the main family unit.

Thus, this study finds that communication is the most important ability for the sustenance of interfaith relationships at the courtship stage. Partners who foster superior interpersonal communication with each other tend to believe that conflict can help increase their knowledge of each other and can thus become a way for them to maintain long-term association and harmony.

\section{REFERENCES}

[1] Acre. (2001). The Experts Story of Courtship. Institute for American Values

[2] Adegbola. O, Labador.A, \& Oviedo. M, (2018). African Students' Identity Negotiation and Relational Conflict Management: Being "Foreign", Being "Careful”, Journal of Intercultural Communication Research, 47:6, 474-490

[3] Berscheid, E., \& Ammazzalorso, H. (2004). Emotional Experience in Close Relationships. In M. B. Brewer \& M. Hewstone (Eds.), Perspectives on social psychology. Emotion and motivation (pp. 47-69). Malden, : Blackwell Publishing

[4] Benokraitis, Nijole V. (1996). Marriages and Families 2nd edition: Changes, Choices and Constraint. New Jersey: Prentice-Hall Inc

[5] Buss, D. M., \& Schmitt, D. P. (1993). Sexual strategies theory: An evolutionary perspective on human mating. Psychological Review, 100, 204232

[6] Cai. D, \& Rodriguez J., I., (1996). Intercultural Adaptation Model. Intercultural Communication Studies.

[7] Clark, A. S., \& Hoover, S. M. (1997). At the intersection of media, culture, and religion. In S. M. 
Hoover, \& K. Lundby (Eds.), Rethinking media, religion, and culture (pp. 15-36). Thousand Oaks, CA: SAGE

[8] Creswell, J. W. (2014). Qualitative inquiry and research design: Choosing among five approaches (4th ed.). Thousand Oaks, CA: Sage Publications

[9] Fiske, A. P., (2002). Using individualism and collectivism to compare cultures - a critique of the validity and measurement of the constructs: comment on Oyserman et al. (2002). Psychological Bulletin, 128, 78-88.

[10] Floyd, F. J., \& Markman, H. J. (1984). An economical observational measure of couples' communication skill. Journal of Consulting and Clinical Psychology, 52(1), 97-103

[11] Gaines, S.O. and Brennan, K.A., (2001). Establishing and maintaining satisfaction in multicultural Relationships. In: J.H. Harvey and A. Wenzel, eds. Close romantic relationships: maintenance and enhancement. Mahwah, NJ: Lawrence Erlbaum, 237-253

[12] Geertz, C. (1973). The interpretation of cultures: Selected essays by Clifford Geertz. New York: Basic Books.

[13] Hurlock, E., (1996). Psikologi Perkembangan Suatu Kehidupan Sepanjang Rentang Kehidupan. Edisi kelima, Penerbit Erlangga, Jakarta

[14] Jackman. A. (2005). How To Negotiate: Teknik Sukses Bernegosiasi. Jakarta: Erlangga

[15] Katzenstein, P., ed. (1996). The Culture of National Security: Norms and Identity in World Politics. New York: Columbia University Press

[16] Koentjaraningrat. (1985). Pengantar Ilmu Antropologi. Jakarta: Aksara Baru.

[17] Kyns, P. (1989). Cinta Muda-Mudi. Pustaka Kaum Muda. Penerbit Kanisius

[18] Martin, J \& Nakayama. (2010). Intercultural communication in contexts. New York. The Mcgraw-Hill companies

[19] Markman, H. J., Renick, M. J., Floyd, F. J., Stanley, S. M., \& Clements, M. (1993). Preventing marital distress through communication and conflict management training: A 4- and 5-year follow-up. Journal of Consulting and Clinical Psychology, 61(1), 70-77

[20] Markovik, E. V. (2007). The mystery method: How to get beautiful women into bed. New York: St. Martin's Press.
[21] McGuire, Meredith B. (2002). Religion: the social context (5th ed.). Wadsworth.

[22] Moore, R. M. (2000). An exploratory study of interracial dating on a small college campus. Sociological Viewpoints, 16, 46-64.

[23] Neuman, W. Laurence. (2010). Social Research Methods: Qualitative and Quantitative Approaches. New York: Pearson.

[24] Niehuis, S. \& L. Huston, Ted \& Rosenband, Reva. (2006). From Courtship Into Marriage: A New Developmental Model and Methodological Critique. The Journal of Family Communication. 6. 23-47.

[25] Oesch, N., \& Miklousic, I. (2012). The Dating Mind: Evolutionary Psychology and the Emerging Science of Human Courtship. Evolutionary Psychology, 10:5.

[26] Pogrebin, L. C. (1987). Among friends. New York: McGraw-Hill.

[27] Robbins, S. P, (2003). Perilaku Organisasi. Index. Jakarta

[28] Samovar, L,A., \& Porter, R (1994). Communication Between Culture. Belmont, California: Wadsworth

[29] Strauss, N. (2009). Rules of the game: The stylelife challenge, the routines collection and the style diaries. New York: It Books.

[30] Yahya, S., Boag, S., Munshi, S., \& Litvak-Hirsch T. (2016). 'Sadly, Not All Love Affairs Are Meant To Be ... 'Attitudes Towards Interfaith Relationships in a Conflict Zone, Journal of Intercultural Studies, 37:3, 265-285

[31] Sewenet, A. M., Tessagaye F.M., \& Tadele, G. (2017). Interreligious Marriage: Social and Religious Perspectives. Imperial Journal of Interdisciplinary Research, 3.

[32] Swann., W. B. (1987). Identity negotiation: Where two roads meet. Journal of Personality and Social Psychology, 53:6

[33] Ting-Toomey, S. (1999). Communicating across cultures. New York: Guilford Press

[34] Vignoles, V. L. (2017). Identity: Personal AND Social. Oxford Handbook of Personality and Social Psychology (2nd ed)

[35] Yahya S, \& Boag S,. (2014). My Family Would Crucify $M e$ The Perceived Influence of Social Pressure on Cross-Cultural and Interfaith Dating and Marriage. Springer Science+Business Media New York. 
[36] Yahya, S., Boag, S., Munshi, S., \& Litvak-Hirsch T,. (2016). 'Sadly, Not All Love Affairs Are Meant To Be ... 'Attitudes Towards Interfaith Relationships in a Conflict Zone, Journal of Intercultural Studies, 37:3, 265-285
[37] Wach, J. (1977/1944). Sociology of Religion. Chicago: The University of Chicago Press. 